\title{
Appendix: Demographic Table of Research Participants
}

\author{
Participants (listed in order of interviews)
}

Neil: Mid-40s, self-employed IT/AV consultant, works mainly in the City and has done for over 20 years.

Maria: Late 30s, head of HR for a global investment firm, a full-time City worker for her entire 20-year career.

Jennifer: Late 40s, Chartered Surveyor, was City based for several years and now has a portfolio career, including lecturing in business and management.

Jo: Early 50s, works as a Freelance Account Director for a large outsourcing organisation, all her clients are City based, so $90 \%$ of her working time is spent in the City, supplemented by time working at home or at Head Office in Holborn. She has worked in the City throughout the last 30 years.

Pete: 40s, partner in an insurance firm, has worked there for 26 years. He has always worked in the City apart from a short spell working locally (Kent) at the start of his career.

Robert: Late 40s, Technical Services Manager for an insurance firm, has worked there for 23 years, and for 30 years in the insurance sector in the City.

Anna: Late 30s, part-time Press and Communications Manager for an Investment Bank, has worked in her present company for 10 years.

Dave: 30s, Business Development Director for an Asset Management Company, has worked in the City for four years.

Phillip: 60s, Semi-retired Former Actuary, worked in the City for 40 years, now runs a consulting business dealing mainly with actuarial firms.

Ian: 40s, Independent Financial Advisor, City based with City-based clients. Apart from spells working abroad for the same firm, he has been City based throughout his working life.

Nigel: 50, Operations Director for a Lloyds's Insurance Agent, has worked in the City for 24 years.

Claire: 40s, worked in Investment Banking in the City for a number of years before moving to fundraising in the Arts.

Tim: Early 20s, Software Developer in a technology start-up which has recently located to the City.

Matt: Mid-20s, Software Developer for a technology start-up, as above.

Nathan: Late 20s, Projects Director for a technology start-up, as above.

Sasha: Early 20s, Business Development Manager for a technology start-up, as above.

Elizabeth: Late 40s, partner in a global professional services firm, she has worked in the City for 25 years.

Lorraine: Mid-20s, works as a PA for an investment company, and has worked in the City for five years. 